\title{
Remote Sensing in Predicting Development Patterns of Built-up Land
}

\author{
Iqbal Eko Noviandi', Alvien Hanif Ramadhan ${ }^{1}$, Rahma Nur Hasanah ${ }^{1}$, Nandi ${ }^{2}$ \\ ${ }^{1}$ Geography Information Science Study Program, Faculty of Social Science Education, Universitas Pendidikan Indonesia, Jl. Dr. \\ Setiabudi No.229, Ledeng, Kec. Cidadap, Kota Bandung, Jawa Barat 40154 \\ ${ }^{2}$ Department of Geography Education, Faculty of Social Science Education, Universitas Pendidikan Indonesia, Jl. Dr. Setiabudi \\ No.229, Ledeng, Kec. Cidadap, Kota Bandung, Jawa Barat 40154
}

Dikirim:
14 September 2021
Direvisi:
18 Oktober 2021
Diterima:
25 Oktober 2021
*Email Korespondensi:
iqbal.en14@upi.edu
A c) (9)

Abstract Indonesia is a developing country whose construction and development are centered on the island of Java, especially in West Java Province. Sukabumi City is one of the areas in West Java. The development of urban areas is expanding due to various human needs to carry out the construction of buildings. Remote sensing that can be used to store developments with multi-temporal analysis with materials is Landsat imagery from 2001 to 2020. The method used is the Normalized Difference Built-up Index (NDBI). The purpose of this study is to map the development of the built-up land from year to year and predict the following years. The results of the research on the significant changes in built-up land occurred between 2013-2020, while from 2001 to 2013 there was not much change. Based on the research results, the total growth of built-up land was $1.539 \%$ per year with a population growth rate of $1.4 \%$ per year. The results of the analysis show that the area of land built in Sukabumi City in 2028 is 186,7194 km2 or has increased by $21,2808 \mathrm{~km} 2$ since 2020.

Keywords: Remote sensing, Build-up Index, Urban Prediction, Geographic information system

\section{INTRODUCTION}

Indonesia is a developing country with a population of around 270 million people. With a large and increasing population, people need building space for living and interacting. Land development also occurred massively, especially in West Java Province. Sukabumi City is one of the areas in West Java that has experienced land development as a center of activity. The area that used to be a green land cover turned into a built-up area due to various kinds of human needs. The variety of activities and the increasing number of immigrants have implications for the increasing need for space for settlements and supporting facilities and infrastructure (Yuliastuti \& Fatchurochman, 2021).

Built-up land is a type of land that has been developed by humans. This development can be in the form of human habitation itself or a place to promote economic activities. Population growth that continues to increase will result in increased demand for built-up land. Therefore, the process of changing natural land into built-up land is one way to overcome the problem of high demand for builtup land. The built-up land expansion requires some control by the government because it directly impacts the ecological functions (Ridwana et al., 2021).

The development of urban growth is always associated with the development of built-up land around the city. This is because the built-up land is a physical characteristic of urban development that can be felt. A developing city is a city that is expanding and has more land to build. (Zahrotunisa \& Wicaksono, 2017). The growth in Sukabumi City can be seen through satellite images from various years from 2001 to 2020 . It could be seen from the satellite image that from year to year the green vegetation will decrease and be replaced with builtup land which usually appears brown and white in the image.

Remote sensing can be a method to monitored land development or change in an area with multitemporal analysis. Multi-temporal is one type of analysis that displays the results of recording remote sensing satellite images that have different times. Multi-temporal analysis with remote sensing data can help in the continuous monitoring of urban development so that it can be used for predicting the development of built-up land (Zahrotunisa \& Wicaksono, 2017).

Landsat is the oldest scientific satellite that has operated since 1972. Landsat has medium image resolution and has had eight versions from Landsat 1 to Landsat 8. The development of Landsat evolves according to the development of existing remote sensing technology. This image can be accessed free as a form of continuous observation of the earth's surface (Hendrawan et al., 2020). Therefore in this study, the satellite images used were Landsat- 7 and Landsat- 8 satellite images with a time of 2001 to 2020 .

A suitable method for monitoring the development of built-up land is the Normalized Difference Built-up Index (NDBI) method. NDBI is used to map changes in built-up land as has been researched by (Suwarsono \& Khomarudin, 2017) which uses Landsat 8 in detecting settlements around active volcanic mountains, (Hidayati et al., 2018) and (Hendrawan et al., 2020) uses Satellite Imagery in the analysis of built-up land in urban areas. The results of the literature study state that the NDBI method can be a quick and better 
alternative in mapping the development of built-up land from year to year.

In predicting future land use, several earlier studies try to predict using several methods. One of the methods used is the Cellular Automata method. This research was conducted by (Cahyadi et al., 2017) which was published in 2017 . This study uses two multi-spectral images at different times (times 1994 and 2001). This study tries to predict the land use of the Garang River Basin in the next 7 and 15 years. The results of this study have been able to display the descriptions of land use in 2008 and 2015. It's just that this research relies on the linear analysis of the two image data which is used as the basis for land use prediction analysis. And also the predictive analysis method in this previous study was not associated with parameters that were strongly suspected to be the reason for the emergence of built-up land so that the development of land use was determined based on the linear nature of the changes that occurred between the two image data used. The parameters referred to in the analysis of the development of built-up land include roads, city centers, slopes, and distance to existing built-up land and other parameters. Therefore, in this study, these parameters are used and used as a reference for the direction of the movement of built-up land in predicting built-up land in Sukabumi City in the next few years.

The purpose of this study was to map the builtup land using Landsat 7-and Landsat-8 satellite imagery in Sukabumi City, as well as to analyze multi-temporal changes in built-up land in the same location. activities to analyze built-up land in the form of assessing capacity change of the Normalized Difference Built-up Index (NDBI) using Landsat-7 and Landsat-8 satellite imagery in Sukabumi City, West Java Province, as well as analyzing changes in built-up land from 2001 to 2020. Development prediction of Sukabumi City in this study visualized spatially using geographic information system technology.

\section{METHODS AND DATA}

This research takes a case study in Sukabumi City and Sukabumi Regency, West Java Province. The administrative area of Sukabumi City is about $48.33 \mathrm{~km}^{2}$ and is the smallest administrative area of the city in West Java. The geographical location of Sukabumi City is at $106^{\circ} 45^{\prime} 50^{\prime \prime}$ East Longitude and $106^{\circ} 45^{\prime}$ 10" East Longitude, 6 49' 29" South Latitude and $6^{\circ} 50^{\prime} 44^{\prime \prime}$ South Latitude. Sukabumi City has 318,117 population in 2020 .

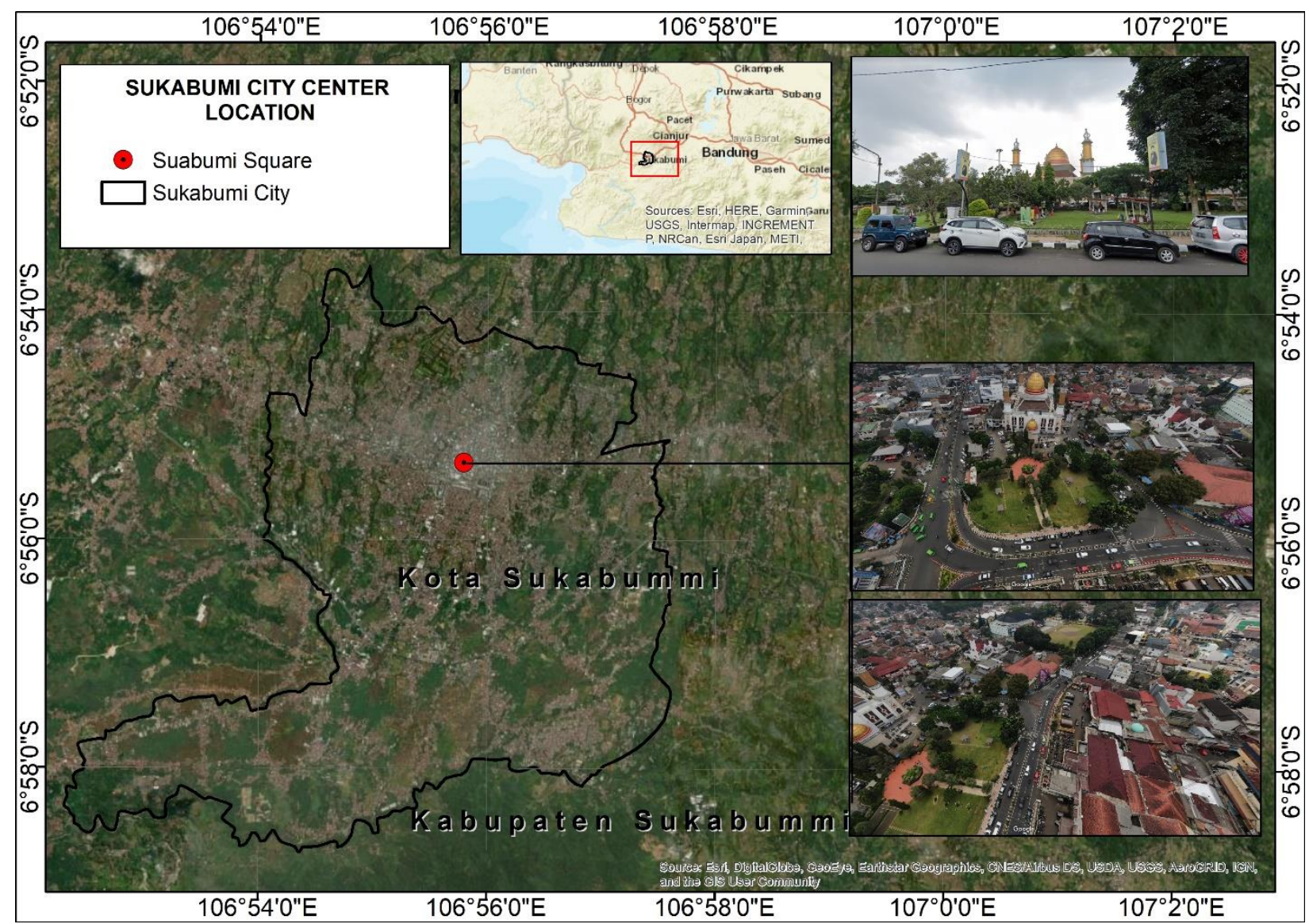

Figure 1. Location map and the position of Sukabumi Square.

Figure 1 Showed the location of the research study, this research focuses on the Sukabumi urban area. Sukabumi City has an official city administrative boundary, but this study does not make the city boundary the boundary of research analysis because this study tries to visualize and 
predict the development of the city. City development will continue to develop its territory so that administrative boundaries are not used as analysis limits. Figure 1 It also shows the research location of the Sukabumi square which will also be used as a center for spatial interactions between other locations in Sukabumi City.

Remote sensing data is used in a study as an attempt to view an image of a surface from the air. One of the advantages of remote sensing is that the images contain various spectral information and data types so that remote sensing can be applied in many applications. Commonly used applications with varying spectral capabilities include land cover classification, natural resource development, remote sensing interpretation, and other applications (Lv et al., 2021). The term multispectral image will refer to the variation of the sensitivity value of a spectral wave on the object being recorded, with a combination of analytical techniques, a multispectral image can be designed to detect a specific study. In this study, multispectral images will be designed to detect the distribution of built-up land in an area study.

The main data used in this research is Landsat Multi-spectral satellite imagery data. The time of this research is from 2001 to 2020 . So the Landsat versions used in this study are Landsat 7 and Landsat 8 . The spatial resolution is 30 meters. The data was obtained from the U.S. Geological Survey (USGS) website (He et al., 2020) and processed using the ArcMap program. The image bands used in this study only take NIR and SWIR1 bands, NIR and SWIR1 bands on Landsat 7 are at $0.772-0.898$ $\mu \mathrm{m}$ and 1.547-1.749 $\mu \mathrm{m}$ while on Landsat 8 are at 0.851-0.879 $\mu \mathrm{m}$ and 1.566-1.651 $\mu \mathrm{m}$.

Table 1. The Landsat 7 \& Landsat 8 Datasets

Landsat Scene ID

Date

LE71220652001132SGS00

$12 / 05 / 2001$

LC81220652013253LGN01

$10 / 09 / 2013$

LC81220652020081LGN00

$21 / 03 / 2020$

The dataset used in this study includes three Landsat scenes. The General information of the Landsat dataset is mention in Table 1 which included the Scene ID and its recording date. Some Landsat datasets not only consider the recording date but also consider the recording quality. The quality of remote sensing data for surface applications is dependent on cloud cover density. The lower the cloud density contained in a recording scene, the better the data quality that can be used in earth surface observation applications.

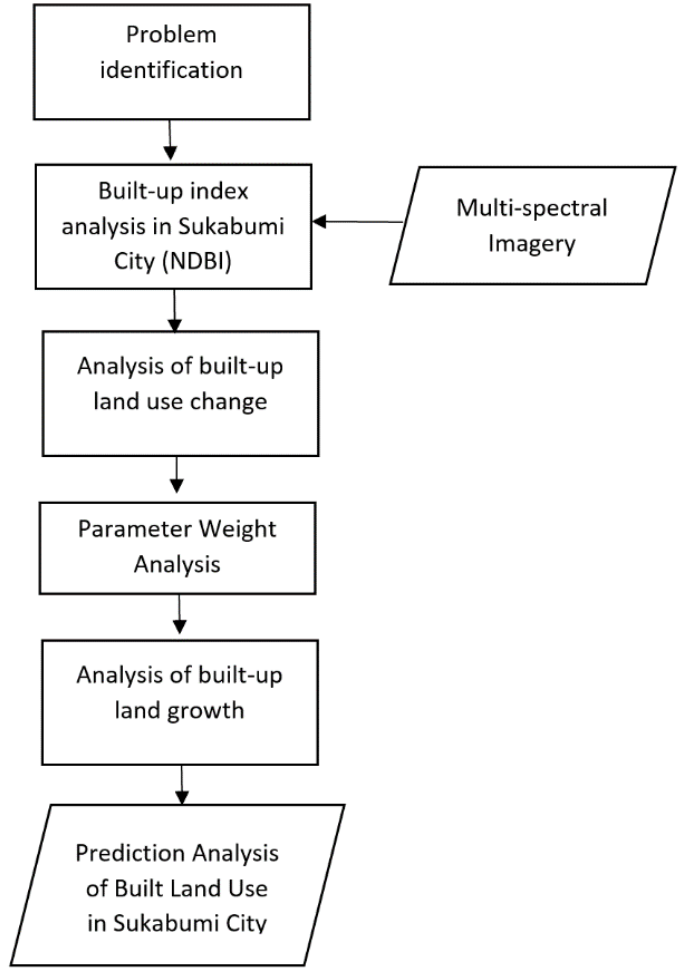

Figure 2. Process of Predicting Development Patterns of Built-up Land

The first step taken is to identify the problem so that it gets a problem about the massive development of built-up land in Sukabumi City. Then from the Multi-spectral satellite imagery (Landsat-7 and Landsat-8) was processed by the NDBI method and then analyzed the changes in land use and the growth of the built-up land. Furthermore, it is connected with the parameters that are suspected to have a strong influence on the direction of the development of a city, the analysis of these parameters will produce predictions of the use of built-up land in Sukabumi City. The results of this study can be used as an evaluation of the development of built-up land in Sukabumi City.

$$
N D B I=\frac{S W I R 1-N I R}{S W I R 1+N I R}
$$

Normalized Difference Built-up Index (NDBI) is a term given in calculating the built-up land index using multi-spectral remote sensing data. Shortwave infrared 1 (SWIR1) is a remote sensing spectral band which is in the spectral value 1.55$1.75 \mu \mathrm{m}$ and near-infrared (NIR) is also a spectral band in the spectral value $0.76-0.90 \mu \mathrm{m}$. The SWIR1 band is sensitive to moisture while the NIR band was more sensitive to the successional regrowth pathway (Negrón-Juárez, et al., 2020; Chen, et al., 2021).

The Normalized Difference Built-up Index or commonly known as NDBI is an algorithm to determine the distribution of built-up land. This algorithm gives a very high value in the area that has the densest building density. This is because 
the land has a very small reflectance value to the vegetation index. This algorithm is very suitable to be used in analyzing the boundaries between builtup land and vegetated land (Hidayati et al., 2018).

The data from the NDBI analysis will have a distribution of data values that vary in the form of a histogram. A high population value will be assumed as built-up land and a low population value will be assumed to be green open land. In this study, the overall population data is divided into five classes by taking the two highest classes which will be assumed as potential built-up land. In dividing these classes, a standard deviation classification approach is used.

$$
\sigma=\sqrt{\frac{\sum(x i-\mu)^{2}}{N}}
$$

In this model, the standard deviation is symbolized as $\sigma$. Each population has a unique value and is symbolized as $x i$. The $\mu$ symbol is the average of the population and $N$ is the size of the population. The high standard deviation category is given to a population that is widely distributed in value, while the low one is population data that is dense and close together at a mean value (Lee et al., 2015). This statement explains that the standard deviation attempts to classify the entire population into several classes where this class interval depends on the distribution pattern of the population on a histogram. This means that the standard deviation has advantages in visualizing the classification of data in a varied and balanced manner.

$$
W=\frac{\overline{\mathrm{y}}}{\sum_{\mathrm{X}=p 1}^{n} \overline{\mathrm{x}}}
$$

In this weight-weighted model, the symbol $w$ is defined as the weight of each parameter. And $p 1$ is parameter $1, x$ is the average of the input variables. then $n$ is the number of parameters. And is the average value of the raster whose weight will be determined. The sum of the mean values of each parameter is simplified using sigma notation in this model.

\section{RESULT AND DISCUSSION}

Landsat-8 Satellite Imagery data after the NDBI analysis process is carried out, five classes are classified. The classification method used is the natural break method by assuming 3 classes with the lowest built-up index value as natural land or non-built land, while the two classes with the highest built-up index value are assumed to be built-up land. This study uses multi-spectral images at different times so that the use of the same classification method can visualize changes in built-up land from year to year.

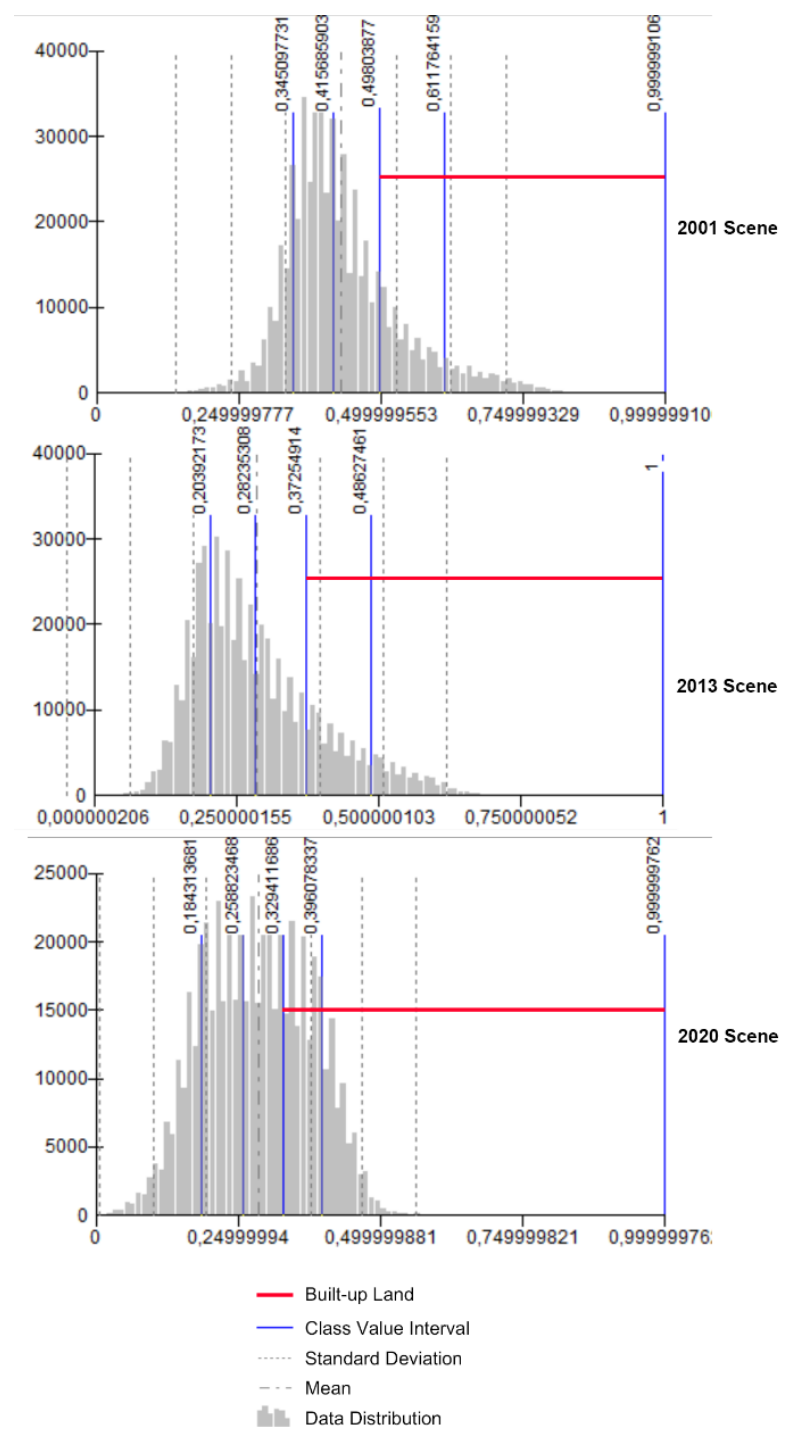

Figure 3. Histogram of each NDBI scene.

The distribution of data that has been visualized using histograms shows that each data is divided into classes based on the amount of data. Then each interval class data decreases its value to a lower value. for example, the minimum interval class limit to categorize the built-up land area decreases from year to year. in 2001, the required value was 0.498 , in 2013 it was 0.372 , and in 2020 it was 0.329 . This happens because every built-up index data has been normalized using a fuzzy membership approach. In the linear fuzzy membership approach, each lowest data value is defined as 0 and the highest value is defined as 1 . This means that the closer to 1 the value of an area, the higher the density of the built-up land at that location.

Based on the comparison of histograms from 2001 to 2013, the data distribution pattern looks more elongated towards the highest value. This means that in this period, the characteristics of the building did not occur much change in the built-up land or there is not much new built-up land in the green open land area. but some of the existing builtup lands experienced an increase in density or the value of the vegetation index in the built-up area Available online at https://jgrs.eng.unila.ac.id/ DOI: https://doi.org/10.23960/igrs.2021.v2i2.61 
decrease. While the period from 2013 to 2020 experienced a change in the pattern of data distribution on the histogram where the histogram shape focused on gathering at the middle value while the graph did not look stretched forward. The meaning of this graph is that the development of built-up land is increasing in areas that were previously green open land areas. Development in this period did not focus on density at a certain point, but on a distributed distribution that meets the requirements to be categorized as built-up land. The development of built-up land in this period occurred very quickly.

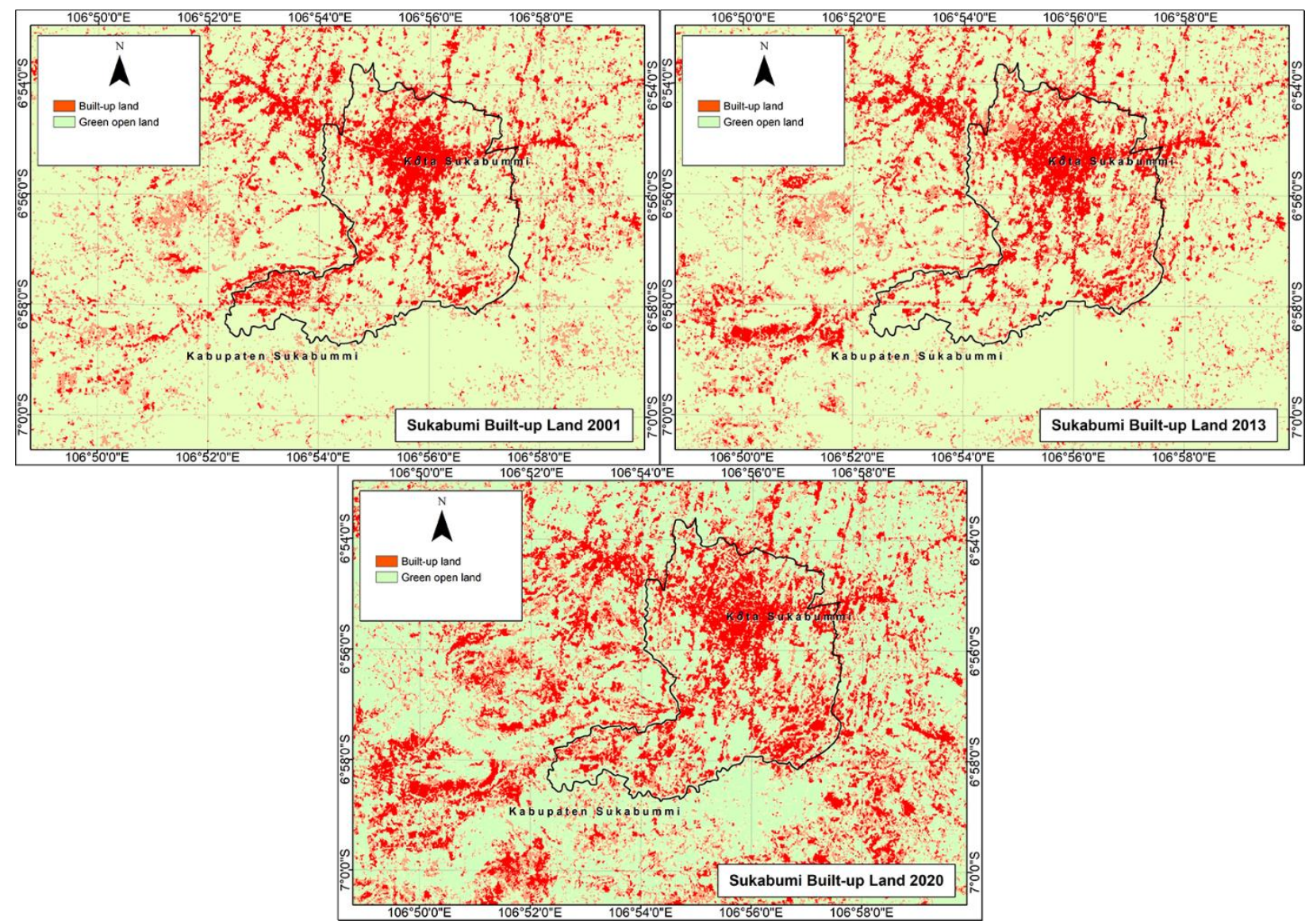

Figure 4. Sukabumi City built-up index maps in 2001, 2013, and 2020.

The results of the Landsat- 8 Satellite Image Visualization that have been carried out by the NDBI analysis process show a red color highlighting the built-up land. In this study, three data sets of Landsat-8 imagery were used in the same location, but with different images. The results will show changes in the characteristics of that location. Based on the image data used, there was a change in built-up land from 2001 to 2020. Significant changes in built-up land occurred between 20132020 while from 2001 to 2013 there were not many changes. This shows that changes in the use of built-up land in Sukabumi City are increasing exponentially. Growth rate analysis is a method used to predict the development of Sukabumi City in the next few years.

To predict the movement of population growth in Sukabumi City. Population growth parameters need to be identified using a weighting analysis of each parameter. The weight is obtained based on the average raster value of each parameter in the area of built-up land growth from 2001 to 2020. This is used as an evaluation in estimating which parameters have the greatest influence on the growth of built-up land in Sukabumi City. The weight results only apply to the location being studied because this analytical method tries to study the nature of the movement of built-up land growth in Sukabumi City so that the results are also used in predicting Sukabumi City in the future.

This study raises five main parameters that are strongly suspected to be the reason for the development of built-up land in a city. The Road parameter was chosen because residential areas need roads as an accessibility measure. People will prefer settlements that are on the side of the road to settlements that do not have road access, This means that the accessibility of road access is very important in the parameters of the emergence of new built-up land in an area. Then the settlement parameters Included because people live in groups. New settlements will grow in areas that have vacant land and are close to other settlements. This will make it easier for people to interact with each other, therefore this parameter is thought to have a strong 
role. Another parameter is the city center parameter, each city has its economic center.

The city center in this study is defined as Sukabumi Square. Sukabumi Square is geographically located in the middle of Sukabumi (The location can be seen in Figure 1) City and has relatively strong spatial interactions in Sukabumi. And then the slope parameter is used because the building requires a flat surface. the influence of gravity will affect the comfort of the community in a new building if the surface is not flat. Although there are various ways to flatten space in an area with a slope, build a settlement on a flat area is more effective and less costly than an area with a high slope. Then the last parameter is the altitude parameter above sea level. If we look at big cities in Indonesia, these cities are relatively located at a low altitude above sea levels such as Jakarta, Surabaya, and Semarang. While in high areas such as mountains, settlements and built-up land are relatively rare. Therefore, this study assumes that the height above sea levels is one of the parameters that is thought to weigh the development of built-up land in an area.
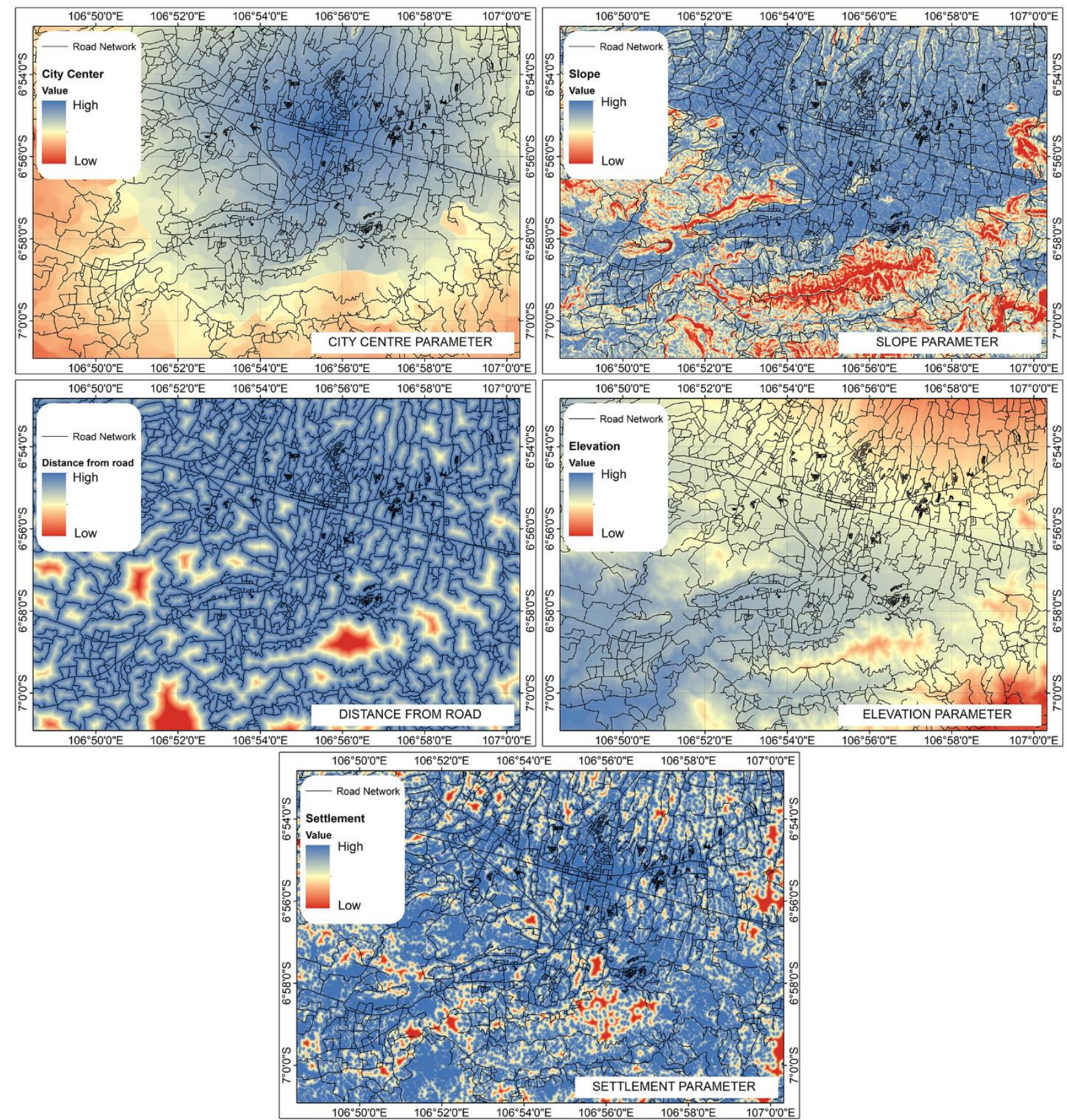

Figure 5. Parameter map of Built-up land in Sukabumi City

To determine the weight of each parameter, each parameter is fuzzy linear right with the maximum raster value $=1$. Each parameter map is extracted with the existing built-up land coverage.

ISSN 2722-3647

ISSN 2722-3639 (e)
So that the average raster for each parameter can be known using statistical tools in ArcMap (Geographic information system). Each parameter DOI: https://doi.org/10.23960/igrs.2021.v2i2.61 
average value will be calculated using formula 2 to get the weight of each parameter that will be used.

Table 2. Parameter weight percentage

\begin{tabular}{ll}
\hline Parameter & Weight \\
\hline Distance from sea level & $16,774 \%$ \\
Distance from road & $23,897 \%$ \\
Distance from settlement & $25,448 \%$ \\
Slope & $21,792 \%$ \\
Distance from city center & $12,089 \%$ \\
\hline
\end{tabular}

After the analysis, the weight of each parameter is known. The parameter that has the biggest role in the development direction of built-up land in Sukabumi City is the distance to existing settlements with a weight of $25.448 \%$. Then the parameter that has the smallest weight in the development analysis of Sukabumi City is the distance to the city center. The center point of the city taken in this study is Sukabumi square. The distance method between the city center points uses Isochrone map analysis or maps that link the distance to the existing road network so that access to the center of Sukabumi City is more relevant than the buffer method.

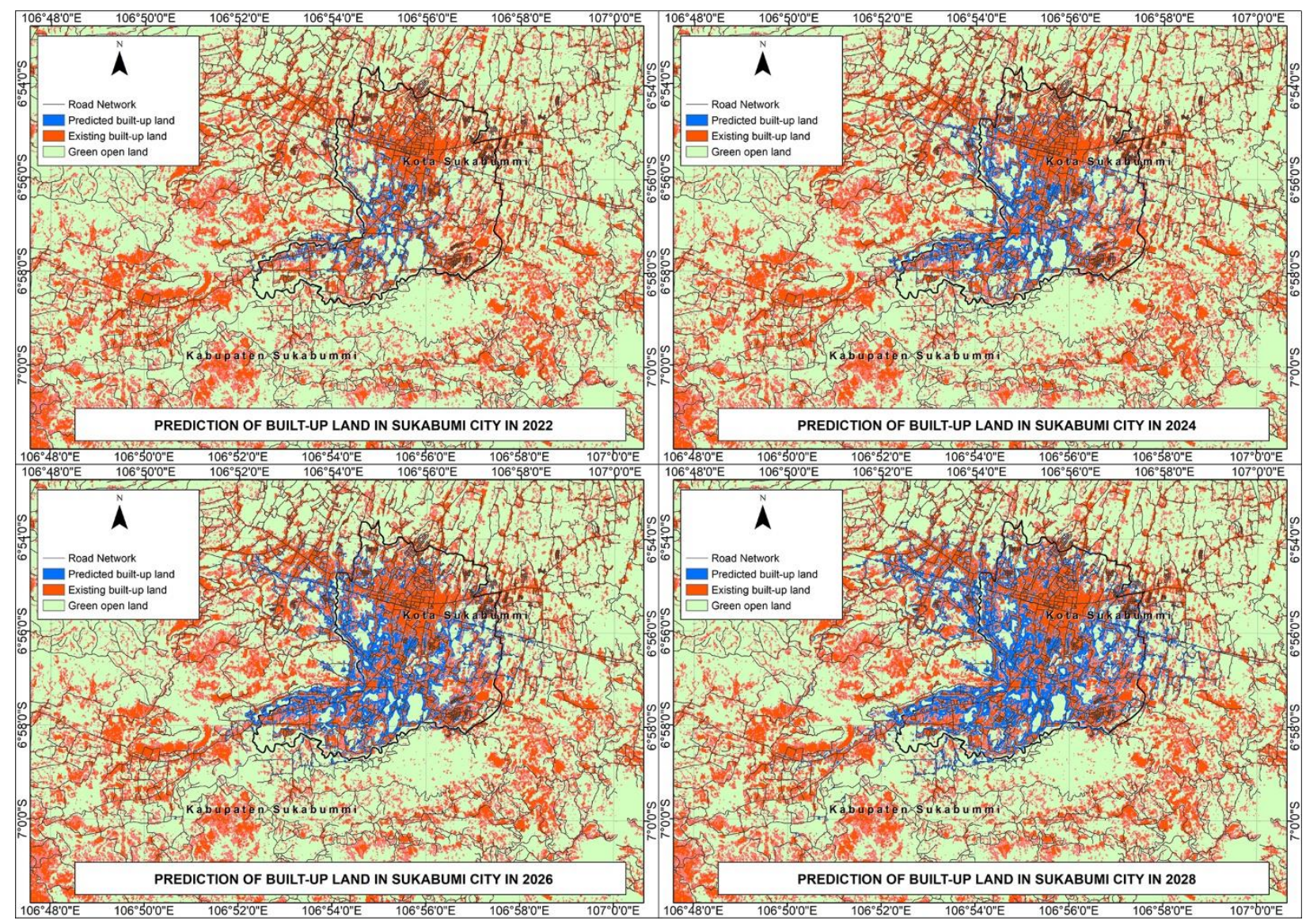

Figure 6. Prediction Map of Sukabumi City's built-up land development in 2022, 2024, 2026, 2028

The results of the visual analysis show that the prediction of built-up land in the next few years will relatively grow in the area around the center of Sukabumi City. Built-up land is predicted to start spreading from the middle of the city and start to spread around existing settlements because it has the largest weight, which is $25.448 \%$.

Built-up land is also predicted to be relatively spread out around the road network. if seen in Figure 6. The existing Road Network will be associated with settlements. Although the weight of the distance from the city center is the smallest, this parameter can still be calculated its role and its role can also be seen with the emergence of built-up land which is relatively included in the administrative scope of Sukabumi City.
Table 3. Built-up area

\begin{tabular}{ll}
\hline Year & $\begin{array}{l}\text { Built-up area } \\
\left(\mathbf{K m}^{2}\right)\end{array}$ \\
\hline 2001 & 92,3612 \\
2013 & 97,5825 \\
2020 & 165,4386 \\
\hline
\end{tabular}

Based on growth analysis, from 2001 to 2013 there was an increase in the amount of land built by $5.6 \%$ over 12 years. while from 2013 to 2020 . the population increased by $69.53 \%$. because the data used are only 3 multi-spectral images, to predict future population growth is by averaging the two

Available online at https://jgrs.eng.unila.ac.id/ DOI: https://doi.org/10.23960/igrs.2021.v2i2.61 
amounts of built-up land growth which used as a reference for built-up land growth. so that the future land growth in 19 years is $29.254 \%$. or $1.539 \%$ per year.

In predicting the development of built-up land, some shortcomings need to be considered. This research does not consider the spatial plan map which is an important parameter. Every city must have a spatial plan in the next few years. This is used as an effort to control patterns in a city. In the process of making a spatial plan map, the government takes maximum effort in considering the movement direction of a city in the future. Therefore, the parameters of the spatial plan will provide a more realistic visualization if they are included in this study. When the spatial planning parameters in the next few years are applied to the prediction of urban development using remote sensing techniques. The visualization results will look more realistic and have a higher chance of similarity with future field conditions. Of course, this is not possible without the participation of the government's role as the controller of the policies that have been made.

Another drawback in this study is that it requires a lot of multi-temporal remote sensing data. Relying on three NDBI data that have different time is still not enough to understand the direction of the NDBI movement. The thing that affects this research using only three Landsat data is due to the availability of data were at other times, remote sensing data is relatively covered by clouds in the coverage area of Sukabumi City. Cloud-covered areas will directly affect the results of the land-built pattern in Sukabumi City. Another drawback is that the parameters that affect the movement of the built-up land need to be added and reviewed. These parameters directly affect the predictive visualization pattern and the linear growth method must also be considered or another better approach in researching predicting the pattern of built-up land in an urban area.

\section{CONCLUSION}

Based on the results of the study, it was found that the amount of built-up land grew by $1.539 \%$ per year. The population growth rate of Sukabumi city is $1.4 \%$ annually. Judging from these two variables, it is predicted that the Population Density of Sukabumi City will comply due to the growth of builtup land which is higher than the population growth rate in Sukabumi City. Based on the results of the analysis, it is predicted that built-up land will begin to appear in the suburbs of the city center because the city center is one of the indicators used in predicting the analysis of built-up land with a weight of $15 \%$ of the total prediction parameters used. The broad coverage of this research area is not bordered by the administration, but by Sukabumi City and the suburbs of Sukabumi City. Based on the results of the growth analysis, the built-up area of the research location in 2028 is $186.7194 \mathrm{~km} 2$ or has increased by $21.2808 \mathrm{~km} 2$ since 2020 . The results of this study are expected to be used as a reference in seeing the development of Sukabumi City in the future.

\section{REFERENCES}

Ali, M. I., Hasim, A. H., \& Abidin, M. R. (2019). Monitoring the Built-up Area Transformation Using Urban Index and Normalized Difference Built-up Index Analysis. International Journal of Engineering, 32(5), 647-653. doi:10.5829/ije.2019.32.05b.04

Ali, M. I., Hasim, A. H., \& Abidin, M. R. (2019). Monitoring the Built-up Area Transformation Using Urban Index and Normalized Difference Built-up Index Analysis. International Journal of Engineering, 32(5). doi:10.5829/ije.2019.32.05b.04

Cahyadi, A., Wacano, D., Yananto, A., \& Wijaya, M. S. (2017). Keterbatasan dan KendalaKendala dalam Prediksi Penggunaan Lahan Masa Depan Menggunakan Metode Cellular Automata (Studi Kasus Pemodelan Prediksi Penggunaan Lahan DAS Darang Tahun 2015). 19-28. doi:10.31227/osf.io/qube7

Chen, Y., Peng, Z., Ye, Y., Jiang, X., Lu, D., \& Chen, E. (2021). Exploring a uniform procedure to map Eucalyptus plantations based on fused medium-high spatial resolution satellite images. International Journal of Applied Earth Observation and Geoinformation, 103, 102462. doi:10.1016/j.jag.2021.102462

Firozjaei, M. K., Sedighi, A., Kiavarz, M., Qureshi, S., Haase, D., \& Alavipanah, S. K. (2019). Automated Built-Up Extraction Index: A New Technique for Mapping Surface BuiltUp Areas Using LANDSAT 8 OLI Imagery. Remote Sensing, 11(17). doi:10.3390/rs11171966

Hanif, M., \& Nofrizal, A. Y. (2019). HUBUNGAN PERKEMBANGAN LAHAN TERBANGUN PERKOTAAN DENGAN FENOMENA IKLIM MIKRO URBAN HEAT ISLAND. Jurnal Spasial, 4(3), 97-103. doi:10.22202/js.v4i3.2507

He, Q., Zhang, Z., Ma, G., \& Wu, J. (2020). GLACIER IDENTIFICATION FROM LANDSAT8 OLI IMAGERY USING DEEP U-NET. ISPRS Annals of the Photogrammetry, Remote Sensing and Spatial Information Sciences, V-3-2020, 381-386. doi:10.5194/isprs-annals-v-32020-381-2020

Hendrawan, Marzuki, Muliadi, \& Azhari, A. P. (2020). Sebaran Lahan Terbangun Berdasarkan Normalized Difference Builtup Index Citra Landsat 8 di Kota Mataram Distribution of Built Land Based on 
Normalized Difference Built-up Index Landsat 8 Imagery in Kota Mataram. SainsTech Innovation Journal, 3(1), 35-40.

Hidayati, I. N., Suharyadi, R., \& Danoedoro, P. (2018). Kombinasi Indeks Citra untuk Analisis Lahan Terbangun dan Vegetasi Perkotaan. Majalah Geografi Indonesia, 32(1), 24-32. doi:10.22146/mgi.31899

IVAN, K., \& BENEDEK, J. (2017). The assessment relationship between land surface temperature (LST) and built-up area in urban agglomeration. Case study: ClujNapoca, Romania. Geographia Technica, 12(1), 64-74. doi:10.21163/gt_2017.121.07

Lee, D. K., In, J., \& Lee, S. (2015). Standard deviation and standard error of the mean. Korean Journal of Anesthesiology, 68(3), 220. doi:10.4097/kjae.2015.68.3.220

Lv, N., Ma, H., Chen, C., Pei, Q., Zhou, Y., Xiao, F., \& Li, J. (2021). Remote Sensing Data Augmentation Through Adversarial Training. IEEE Journal of Selected Topics in Applied Earth Observations and Remote Sensing, 14, 9318--9333. doi:10.1109/jstars.2021.3110842

Negrón-Juárez, R. I., Holm, J. A., Faybishenko, B., Magnabosco-Marra, D., Fisher, R. A., Shuman, J. K., . . Chambers, J. Q. (2020). Landsat near-infrared (NIR) band and ELMFATES sensitivity to forest disturbances and regrowth in the Central Amazon. Biogeosciences, 17(23), 6185-6205. doi:10.5194/bg-17-6185-2020

Nofrizal, A. Y. (2017). NORMALIZED DIFFERENCE BUILT-UPINDEX (NDBI) SEBAGAI PARAMETER IDENTIFIKASI PERKEMBANGAN PERMUKIMAN KUMUH PADA KAWASAN PESISIR DI KELURAHAN KALANG KAWAL, KECAMATAN GUNUNG KIJANG, KABUPATEN BINTAN. Tunas Geografi, 6(2), 143-150. doi:10.24114/tgeo.v6i2.8572

Noraini, A., \& Mabrur, A. Y. (2020). Perbandingan Visualisasi Hasil Deteksi Area Terbangun Berdasarkan Metode Maximum Likelihood Classification (MLC) dan Normalized Difference Built-Up Index (NDBI). Buletin Loupe, 16(01), 21-26. doi:10.51967/buletinloupe.v16i01.113

Nurhidayati, E., \& Fariz, T. R. (2020). Analisis Regresi Logistik Untuk Identifikasi Faktor Pendorong Pertumbuhan Lahan Terbangun Secara Spasial di Kota Pontianak. UNIPLAN: Journal of Urban and Regional Planning, 1(1), 40-47. doi:10.26418/uniplan.v1i1.43043

Putra, D. R., \& Pradoto, W. (2016). POLA DAN FAKTOR PERKEMBANGAN PEMANFAATAN LAHAN DI KECAMATAN
MRANGGEN, KABUPATEN DEMAK. Jurnal Pengembangan Kota, 4(1), 67-75. doi:10.14710/jpk.4.1.67-75

Rasskazova, A., \& Sinits, Y. (2019). Prediction of agricultural land use. (IOP) Conference Series: Earth and Environmental Science, 350. doi:10.1088/1755-1315/350/1/012068

Ridwana, R., Sugandi, D., Arrasyid, R., Himayah, S., \& Pamungkas, T. D. (2021). Multitemporal landsat image utilization for spatial prediction of built up area in tasikmalaya city, indonesia. IOP Conference Series: Earth and Environmental Science. 683, p. 012101. Orlando: IOP Publishing. doi:10.1088/1755-1315/683/1/012101

Solihin, I. P., \& Kurniyanto, R. (2021). Pemanfaatan Citra Landsat 8 Untuk Estimasi Luas Lahan Terbangun dan Tidak Terbangun pada Kota Bandung. Jurnal Indonesia Sosial Teknologi, 2(5), 816-827. doi:10.36418/jist.v2i5.150

Suwarsono, \& Khomarudin, M. R. (2017). DETECTING THE SPATIAL DISTRIBUTION OF SETTLEMENTS ON VOLCANIC REGION USING IMAGE LANDSAT-8 OLI IMAGERY. International Journal of Remote Sensing and Earth Sciences (IJReSES), 11(1), 63-72. doi:10.30536/j.ijreses.2014.v11.a2602

Syafitri, R. A., \& Susetyo, C. (2019). Pemodelan Pertumbuhan Lahan Terbangun Sebagai Upaya Prediksi Perubahan Lahan Pertanian di Kabupaten Karanganyar. Jurnal Teknik ITS, 7(2). doi:10.12962/j23373539.v7i2.36453

Yin, I., Tan, M. L., Lin, T. Y., Mohamad, D., \& Ghapar, A. (2019). Monitoring Land Use Pattern And Built-Up Expansion In Kuala Lumpur City Centre. The European Proceedings of Multidisciplinary Sciences (pp. 200-2014). Cognitive-Crcs. doi:10.15405/epms.2019.12.20

Yuliastuti, N., \& Fatchurochman, A. (2021). PENGARUH PERKEMBANGAN LAHAN TERBANGUN TERHADAP KUALITAS LINGKUNGAN PERMUKIMAN (Studi Kasus: Kawasan Pendidikan Kelurahan Tembalang). Jurnal Presipitasi : Media Komunikasi dan Pengembangan Teknik Lingkungan, 9(1), 10-16.

Zahrotunisa, S., \& Wicaksono, P. (2017). Prediksi Spasial Perkembangan Lahan Terbangun Melalui Pemanfaatan Citra Landsat Multitemporal di Kota Bogor. Jurnal Online Informatika, 2(1), 30-35. doi:10.15575/join.v2i1.88 